\title{
Crop rotation and soil scarification: impacts in the soil penetration resistance
}

\author{
Alexandra da Silva Martinez*, Edleusa Pereira Seidel, Renan Pan, Tauane Santos Brito, Wesler Meiners \\ Caciano and Leticia Gabriela Ertel
}

State University of Western Paraná, Marechal Cândido Rondon, PR, Brazil

*Author for correspondence: alexandra26martinez@gmail.com

\begin{abstract}
OPEN ACCESS
(C) The Authors

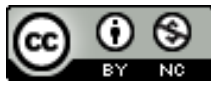

Submitted on May 27, 2019 Accepted on October 07, 2019 Early View on October 08, 2019 Final Publication on October 10, 2019

Authors declare no conflict of interest

KEYWORDS: Winter cover crops Soil decompression Soil and water management Soil and water conservation

\section{ABSTRACT}

The objective of the present study was to evaluate the soil penetration resistance of an Oxisoil under a crop rotation system with mechanical and/or biological scarification. A randomized block design, with four replicates, was used, with the following treatments: sowing of a mix of forage radish and black oat followed by mechanical scarification right after it was sowed; sowing of a mix of forage radish and black oat without mechanical scarification sowing of maize second crop and scarification right after its harvest; sowing of maize second crop with sowing of buckwheat right after its harvest; sowing of maize second crop (control). All treatments were followed by the sowing of soybean in October 2018. It was evaluated, in five spots per plot, the soil penetration resistance in the $0-40 \mathrm{~cm}$ depth, with the digital penetrometer Falker® PLG 1020. All treatments presented a reduction in the soil penetration resistance, with values inferior to $2.00 \mathrm{MPa}$, which is the critical limit for most crops. In all treatments tested, the penetration resistance tended to equality in the depth of $40 \mathrm{~cm}$.

\section{Highlighted Conclusion}

The mechanical scarification can be used to increase the soil water infiltration since results in improvements in the soil physical properties if performed right after the mix of forage radish and black oat was sowed or right after the maize harvest.
\end{abstract}

\section{INTRODUCTION}

The crop rotation technique provides improvements to the soil chemical properties, restocking nutrients that are removed from the deepest layers and placed as organic matter (Signor et al. 2016). Also, physical improvements, increasing the organic matter and improving the aggregation, porosity and soil structure (Yazdanpanah et al. 2016); and biological, acting in the supply of nutrients and in the macro and microfauna plurality.

One of the advantages of the crop rotation system is the biological scarification, due to the root system growth; capable of reducing the compaction of the sub superficial soil layers (Calonego et al. 2011, Valicheski et al. 2012); increasing its porosity. The soil compaction is due to inadequate management and causes a reduction in the crop's productivity. Some farmers and researchers have been working with the soil mechanical scarification, in order to remedy these problems, however, this technique have a fast effect, but not very durable to the soil (Nunes et al. 2014, Drescher et al. 2016).

Thus, evaluations comparing the management techniques are necessary, so then it can be established which methods are more efficient to improve the soil physical properties. Among the techniques to evaluate the soil physical properties stand out the macroporosity, microporosity, total porosity, soil density and soil penetration resistance, being the last one considered a good indicative of soil quality; due to the fast evaluation and the data precision (Portugal et al. 2010, Ferreira et al. 2018).

The soil penetration resistance has a limit considered critical which is of $2.00 \mathrm{MPa}$. The soil with this characteristic is considered restrictive to the development of some crops (Soil Survey Staff 2017). Thus, this study has as hypothesis that, when considering the soil penetration resistance evaluation in a crop rotation system and with mechanical and biologic scarification, the biologic scarification system will show similar or smaller values of soil penetration resistance. The objective of the present study was to evaluate the soil penetration resistance of an Oxisoil under a crop rotation system with mechanical and/or biological scarification. 


\section{MATERIAL AND METHODS}

The experiment was carried in the experimental station form the "Universidade Estadual do Oeste do Paraná" located in Entre Rios do Oeste city, Paraná, under the coordinates $24^{\circ} 68^{\prime} \mathrm{S}$ and $54^{\circ} 28^{\prime} \mathrm{W}$ and altitude of $244 \mathrm{~m}$. The region weather, according to the Koppen classification, is classified as Cfa subtropical mesothermic humid (IAPAR 2019). The soil from the experiment is classified as Oxisoil with clay, silt and sand contents of 525, 400 and $75 \mathrm{~g} \mathrm{~kg}^{-1}$, with annual rainfall average of 1,600-1,800 millimeters (Caviglione et al. 2000).

The experiment was implanted in March 2018 in a randomized block design with five treatments and four replicates, in plots of $12 \times 12.5 \mathrm{~m}$, where the treatments were: sowing of forage radish + black oats followed by mechanical scarification after its sowing in May 2018, with desiccation in September and soybean sowing in October 2018 (T1); sowing of forage radish + black oats in May 2018, with desiccation in September and soybean direct sowing in October 2018 (T2); sowing of maize second crop in March 2018 with harvest in August 2018 and immediate scarification after harvest, followed by soybean sowing in October 2018 (T3); sowing of maize second crop in March 2018 with harvest in August 2018 and sowing of buckwheat after the maize was harvested, with desiccation in September 2018, followed by soybean direct sowing in October 2018 (T4); ); sowing of maize second crop in March 2018 with harvest in August 2018 and soybean direct sowing in October 2018 (T5) (control).

For the experiments conduction it was used the maize hybrid DKB 330 PRO, sowed with a sower KUHN SDM $2227 / 29$, in the spacing of $0,5 \mathrm{~m}$ between rows at a $5 \mathrm{~cm}$ depth, with $185 \mathrm{~kg} \mathrm{ha}^{-1}$ of the formula 10-15-15. The forage radish and black oats 139 BRS was sowed in May 2018, with a sower Semeato SHM 11/13, in the proportion of 9 and $60 \mathrm{~kg} \mathrm{ha}^{-1}$, respectively, at a $3 \mathrm{~cm}$ depth, with a spacing between rows of $0,17 \mathrm{~m}$ and addition of $185 \mathrm{~kg} \mathrm{ha}^{-1}$ from the formula based on nitrogen, phosphorus and potassium in the 10-15-15 concentration. The scarification was made with scarificator SPDA with seven legs spaced at $37 \mathrm{~cm}$, and $7,5 \mathrm{~cm}$ wide points, with a work depth of $40 \mathrm{~cm}$. The buckwheat cultivar IPR 91 was sowed at $2 \mathrm{~cm}$ depth with manual sower Knapik ${ }$, without fertilizer, in a spacing between rows of $35 \mathrm{~cm}$, in the sowing density of $9 \mathrm{~kg} \mathrm{ha}^{-1}$.

Evaluations were made with penetrometer Falker® PLG 1020, in three periods, (March 2018, October 2018 and March 2019), in the 0-40 cm soil layer, being the apparel regulated to make readings every $1 \mathrm{~cm}$, with posterior data stratification to $5 \mathrm{~cm}$. Were collected five points per plot, totalizing 20 points per treatment and 100 points for all the experiment.

Data were tabulated and submitted to the Shapiro-Wilk normality test. In the presence of normality, Fisher's F test at $5 \%$ probability of error was analyzed for variance. If significant, were submitted to the Tukey's test at $5 \%$ probability of error. All analyses were made with aid of the statistic software Sisvar (Ferreira 2014).

\section{RESULTS AND DISCUSSION}

Figure 1 shows the mean values of soil penetration resistance for March 2018. In function of the observed results, it is stood out that all treatments presented values of soil penetration resistance inferior to $2.00 \mathrm{MPa}$ only for the 30 to $40 \mathrm{~cm}$ depth. This occurs due to the direct sowing system that benefits the formation of more compacted layers on the surface.

However, these results differ from the observed by Drescher et al. (2012), where, in direct sowing system for eight consecutive years, found values of soil penetration resistance inferior to the ones found in this experiment, for the $5-25 \mathrm{~cm}$ layer, shown in the Figure 1. This characteristic may have occurred due to a better system consolidation that, according to Salton et al. (2012) defines as the characteristics of a consolidated direct sowing system the absence of soil revolving, the crop rotation and, consequently, the permanent soil coverage.

In the Figure 2, the treatment 3 showed smaller values of soil penetration resistance in the $15-25 \mathrm{~cm}$ layer. The treatment 1 showed satisfactory results of soil penetration resistance for the $15-25 \mathrm{~cm}$ layer. The treatments 1 and 3 were the only ones that did not present penetration resistance values superior to the limit of $2.00 \mathrm{MPa}$ in the evaluated depths.

Drescher et al. (2012) testing the soil scarification and different managements highlighted that scarified soils presented penetration resistance, in the $5-30 \mathrm{~cm}$ layer, superior to the ones found in this research for the treatments with scarification (Figures 2 and 3 ).

The Figure 3 have the soil penetration resistance means after the plants were managed, and the soybean was harvested. According to the obtained data, all treatments showed a satisfactory reduction in the soil penetration resistance, without means superior to $2.00 \mathrm{MPa}$. These values fall within the category of moderate resistance to penetration, as Soil Survey Staff (2017), which report that the penetration resistance classes range from 0.10 up to 8.00 , in a way that a soil with a resistance between 0.10 and $1.00 \mathrm{MPa}$ is considered as of low resistance; between 1.00 and 2.00 of moderate resistance; between 2.00 and 4.00 of high resistance and between 4.00 and 8.00 of very high resistance. 


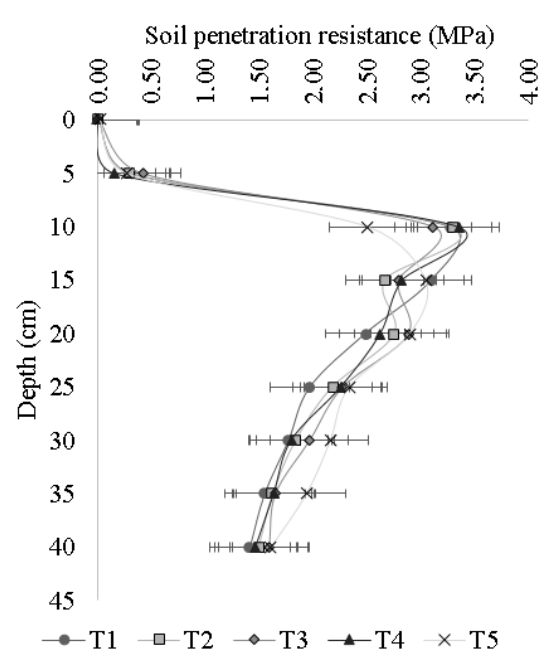

Figure 1. Mean values of soil penetration resistance of an Oxisoil (in MPa), submitted to the crop rotation system, with or without mechanical and biological scarification, referent to March 2018, in Entre Rios do Oeste city, Paraná state. (Soil humidity $20 \%$ ).

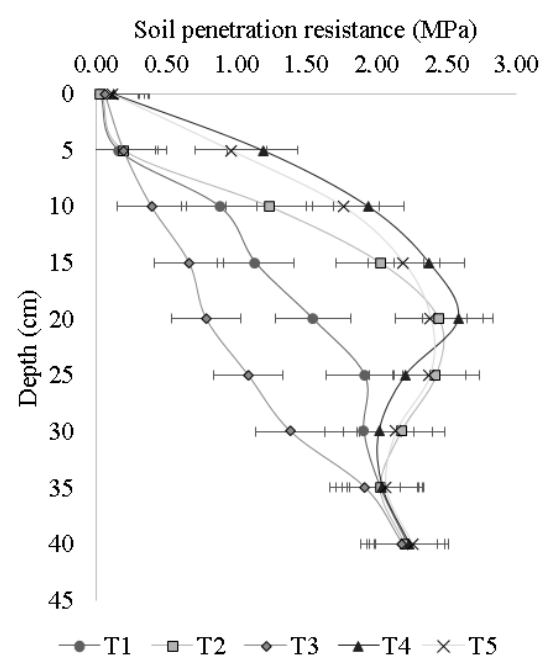

Figure 2. Mean values of soil penetration resistance of an Oxisoil (in MPa), submitted to the crop rotation system, with or without mechanical and biological scarification, referent to October 2018, in Entre Rios do Oeste city, Paraná state. (Soil humidity $19 \%$ ).

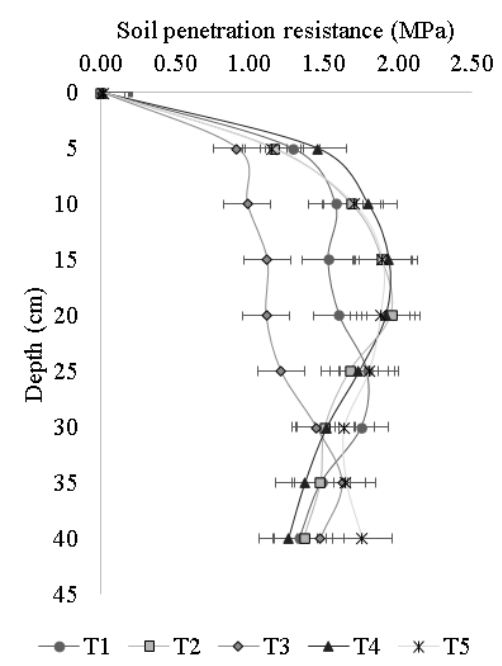

Figure 3. Mean values of soil penetration resistance of an Oxisoil (in MPa), submitted to the crop rotation system, with or without mechanical and biological scarification, referent to March 2019, in Entre Rios do Oeste city, Paraná state. (Soil humidity $22 \%$ ).

With the objective of testing the effect of cover plants from the Fabaceae family (Pisum sativum L. and Pisum sativum L.) and Poaceae (Avena strigosa S. and Urochloa ruziziensis) over the soil penetration resistance, Mottin et al. (2018) report values soil penetration resistance inferior to $1.50 \mathrm{MPa}$, lower than the ones found in the present study. This may have occurred due to the root system of the plants that were used, in special the black oat, which is a Poaceae with a more aggressive hairy root system, which directly influences in the soil physical properties (Kondo et al. 2012), due to a better soil exploration, influencing in the biopores formation, which reduce the soil penetration resistance. In addition, Cardoso et al. (2013), when testing showy rattlepod, jack beans and millet as cover plants in different spacings, obtained values of soil penetration resistance inferior to $2.00 \mathrm{MPa}$, indicating that the root development of these crops reflects in the soil biopores formation.

On the contrary, Seidel et al. (2017) when testing maize in consortium with Brachiaria brizantha, Brachiaria ruziziensis and black oats obtained values of soil penetration resistance up to $4.00 \mathrm{MPa}$ in the $10-30 \mathrm{~cm}$ layer of an Oxisoil, values that are superior to the ones found in this study. Such results may be justified by the use of a nonconsolidated direct sowing system in the tested area, reflecting in a bad soil physical structure.

According to Valente et al. (2019), soils under tillage system presented smaller soil penetration resistance values only for the $0-10 \mathrm{~cm}$ layer, in comparison to the direct sowing system which presented soil penetration resistance values inferior to the tillage system in the $15-25 \mathrm{~cm}$ layer (average of $1.85 \mathrm{MPa}$ ), similar result to the obtained for the direct sowing treatment (T5) in this study.

In the cultivation of maize with scarification after its harvest and soybean in succession (T3, Figure 3 ) it resulted in smaller values of soil penetration resistance, being them inferior to $1.00 \mathrm{MPa}$ in the $10-25 \mathrm{~cm}$ layer, indicating a persistence in this physical property seven months after it was made. The reduction in the soil penetration resistance occurred in function of the scarificator legs in breaking the soil layers. This change will result in higher water infiltration, smaller surface runoff and in a more favorable environment for the crop's root development.

The mix of forage radish with black oats, followed by mechanical scarification, right after the cover crops sowing (T1) also stood out; because it presented average values of $1.50 \mathrm{MPa}$ of soil penetration resistance for the 10-20 $\mathrm{cm}$ layer after 11 months of its scarification, that is, higher residual effect. Probably due to the root growth effect and of its decomposition (Calonego and Rosolem 2010); acting in the maintenance of the number of soil biopores. No statistical difference between the control (T5) and the mix of forage radish with black oat (T2); maize second crop followed by buckwheat sowing (T4) was observed. For all treatments tested, the soil penetration resistance tended to equal in the depth of $40 \mathrm{~cm}$.

In conclusion, all treatments tested presented a tendency to equality for the evaluations of soil penetration resistance in the depths of $40 \mathrm{~cm}$. The mechanical scarification resulted in longer lasting effects to reduce the soil penetration resistance. 


\section{References}

Calonego JC et al. 2011. Desenvolvimento de plantas de cobertura em solo compactado. Bioscience Journal 27:289-296.

Calonego JC and Rosolem CA. 2010. Soybean root growth and yield in rotation with cover crops under chiseling and notill. European Journal of Agronomy 33:242-249.

Caviglione JH et al. 2000. Cartas climáticas do Paraná. Londrina, Instituto agronômico do Paraná (IAPAR).

Cardoso DP et al. 2013. Espécies de plantas de cobertura no recondicionamento químico e físico do solo. Revista Brasileira de Ciências Agrárias 8:375-382.

Drescher MS et al. 2012. Resistência à penetração e rendimento da soja após intervenção mecânica em Latossolo Vermelho sob plantio direto. Revista Brasileira de Ciência do Solo 36:1836-1844.

Drescher MS et al. 2016. Duração das alterações em propriedades físico-hídricas de Latossolo argiloso decorrentes da escarificação mecânica. Pesquisa Agropecuária Brasileira 51:159-168.

Ferreira CJB et al. 2018. Soil physical properties under a 'Tanzânia' grass pasture fertilized with mineral nitrogen or intercropped with stylosanthes. Pesquisa Agropecuária Brasileira. Brasília 53:478-486.

Ferreira DF. 2014. Sisvar: a guide for its bootstrap procedures in multiple comparisons. Ciencia e Agrotecnologia 38:109-112.

IAPAR - Instituto Agronômico do Paraná. 2019. http://www.iapar.br/modules/conteudo/conteudo.php?conteudo=677.

Kondo MK et al. 2012. Effect of plant cover on soil physical attributes and agronomic characteristics of Sorghum. Bioscience Journal 28:33-40.

Nunes MR et al. 2014. Persistência dos efeitos da escarificação sobre a compactação de Nitossolo sob plantio direto em região subtropical úmida. Pesquisa Agropecuária Brasileira. Brasília 49:531-539.

Mottin MC et al. 2018. Biomass productivity and physical properties of the soil after cultivation of cover plant in the autumn and winter. American Journal of Plant Sciences 9:775-788.

Portugal AF et al. 2010. Propriedades físicas e químicas do solo em áreas com sistemas produtivos e mata na região da zona da mata mineira. Revista Brasileira de Ciência do Solo 34:575-585.

Salton JC et al. 2012. Sistema Plantio Direto. O produtor pergunta, a Embrapa responde. Embrapa-SPI; Dourados: Embrapa-CPAO.

Seidel EP et al. 2017. Physical properties of soil and productivity of maize intercropped with different cover plants. African Journal of Agricultural Research 12:2940-2945.

Signor D et al. 2016. Atributos químicos e qualidade da matéria orgânica do solo em sistemas de colheita de cana-de-açúcar com e sem queima. Pesquisa Agropecuária Brasileira 51:1438-1448.

Soil Survey Staff. 2017. Penetration Resistance Classes. United States Department of Agriculture. 191p.

Valente GF et al. 2019. Resistência mecânica à penetração em sistemas de manejo do solo. Revista Verde 14:140-145.

Valicheski RR et al. 2012. Desenvolvimento de plantas de cobertura e produtividade da soja conforme atributos físicos em solo compactado. Revista Brasileira de Engenharia Agrícola e Ambiental 16:969-977.

Yazdanpanah $\mathrm{N}$ et al. 2016. The impact of organic amendments on soil hydrology, structure and microbial respiration in semiarid lands. Geoderma 266:58-65. 